\title{
Morphosyntactic Study on English Derivational Suffixes Forming Adjectives with Reference to the Twilight
}

\author{
Ni Kadek Yuni Antari ${ }^{1 *}$, I Nyoman Sedeng ${ }^{2}$, Putu Lirishati Soethama ${ }^{3}$ \\ ${ }^{[123]}$ English Department, Faculty of Arts - Udayana University \\ ${ }^{1}$ [yuniantari872@gmail.com] [2[nyoman_sedeng@hotmail.com] \\ ${ }^{3}$ [lirishatinya@yahoo.com] \\ *Corresponding Author
}

\begin{abstract}
The title of this study is "Morphosyntactic Study on English Derivational Suffixes Forming Adjectives with Reference to the Twilight". This study discusses the combination of morphology and syntax called morphosyntax. Morphology is the study about word formation; meanwhile syntax is the study about sentence structure. This study mainly aims at finding out the derivational suffixes forming adjectives and the syntactic functions of the adjective found in the novel Twilight. The data of this study were taken from a novel entitled Twilight by Stephanie Meyer. Library research method was applied in this study in collecting data. It was done by collecting the derivational suffixes forming adjectives, copying the data, and classifying the derivational adjectives found in the novel. The collected data in this study were analyzed using descriptive qualitative method. The main theory applied in this study is the theory of Morphology and Syntax proposed by Quirk, et al (1985). The result of the analysis shows that there were derivational suffixes that can change the word class from noun and verb into adjective. There are ten suffixes found, they are suffix -ful, -able, -ish, -ous, -al, -ic, less, -y, -ive, -ly. Meanwhile, for the syntactic functions there are two types found, they are predicative and attributive.
\end{abstract}

Keywords: Derivational, Suffixes, Adjective

\begin{abstract}
Abstrak
Judul penelitian ini adalah "Morphosyntactic Study on English Derivational Suffixes Forming Adjectives with Reference to the Twiligh". Penelitian ini membahas kombinasi morfologi dan sintaksis yang disebut morfosintaksis. Morfologi adalah studi tentang pembentukan kata; sementara sintaksis adalah studi tentang struktur kalimat. Penelitian ini terutama bertujuan untuk mengetahui akhiran derivatif yang membentuk kata sifat dan fungsi sintaksis kata sifat yang ditemukan dalam novel Twilight. Data penelitian ini diambil dari sebuah novel berjudul Twilight oleh Stephanie Meyer. Metode penelitian kepustakaan diaplikasikan dalam penelitian ini dalam pengumpulan data. Hal itu dilakukan dengan mengumpulkan akhiran derivatif yang membentuk kata sifat, menyalin data, dan mengklasifikasikan kata sifat derivatif yang ditemukan dalam novel tersebut. Data yang terkumpul dalam penelitian ini dianalisis dengan metode deskriptif kualitatif. Teori utama yang digunakan dalam penelitian ini adalah teori Morfologi dan Sintaksis yang dikemukakan oleh Quirk, dkk (1985). Hasil analisis menunjukkan bahwa ada akhiran derivatif yang membentuk kata sifat dapat mengubah kelas kata dari kata benda dan kata kerja menjadi kata sifat. Ada sepuluh akhiran yang ditemukan, diantaranya akhiran -ful, -able, -ish, -ous, -al, -ic, -less, -y, -ive, -ly.
\end{abstract}


Sedangkan untuk fungsi sintaksis ada dua jenis yang ditemukan, yaitu predikatif dan atributif.

Kata kunci: Derivatif, Akhiran, Kata Sifat

\section{Background of the Study}

Language is used for communication. Communication is an important aspect in our daily life. We use language to communicate with people around us. There are lots of languages in the world, one of them is English. As an international language, English needs more attention because it is used in various fields and it becomes an interesting object to be learned by the people especially in many countries who do not use English as their first language. To understand English well we have to know about the aspect of the language itself. One of the important aspects is grammatical aspect which is divided into four linguistic levels; they are phonology, morphology, syntax, and semantics.

Morphology is one of the branches of linguistics. It is the study of word formation. According to Katamba (1993:19) morphology is the study of word structure.In morphology there are two principal word-building processes, such as derivational and inflectional. Inflectional morphemes form new words either without changing the meaning of the base to which they are attached or without changing the word class of the base to which they are attached. Derivational morphemes form new words either by changing the meaning of the base to which they are attached or by changing the word class that a base belongs to.Derivational affixes can be divided into two. They are derivational prefix and suffix. Suffix is an affix attached after root or stem or base, like ly, -er, -ist, -s, -ist, and -ed. Suffixes are divided into four forms (Plag, 2002), namely nominal suffixes, verbal suffixes, adjectival suffixes, and adverbial suffixes.

The study of language is not only concerned with the study of morphology. It is also the study about the grammatical structure of sentences that we call syntax. Essentially, morphology and syntax are studies of the same thing; formation rules of a language. Therefore, the combination of both branches of linguistics is called morphosyntax.

This study analyses English derivational suffixes, especially derivational suffixes forming adjectives and also the syntactical function of adjective itself.The study applied the theories of morphology and syntax proposed by Quirk et al (1985). The analysis was based on derivational suffixes forming adjectives found in the Novel entitled Twilight by Stephanie Meyer. This novel is interesting because it contains various kinds of derivational words and adjectives with different functions. This study is interesting, because people need to learn English word formation and also the rule of word formation; it could give benefit to the learners because it can enrich the vocabulary and knowledge in differentiating the word class, especially derivational suffixes of English word.

\section{Problems of the Study}

Related to the background of the study, the problems are formulated as follows:

a. What kinds of derivational suffixes forming adjectives are found in the novel Twilight? 
b. What are the syntactic functions of derivational adjectives found in the novel Twilight?

\section{Aims of the Study}

Related to the background and the problems of the study, the aims are explained as follows:

a. To find out the derivational suffixes forming adjectives found in the novel Twilight.

b. To analyze the syntactic functions of derivational adjectives found in the novel Twilight.

\section{Research Method}

Methodology is a procedure in doing research. It is an important factor that should be used as a guide by researchers. Research method can be defined as the way used in solving the problems. The term methodology is also related to the term of research method. The research method of this study is divided into four. There are data source, method and technique of collecting data, method and technique of analyzing data, and method and technique of presenting analysis.

\subsection{Data Source}

Data source is the first element in methodology. It deals with the source from which the data are taken. The data source of this study is a novel entitled Twilight by Stephanie Meyer. It is the first edition published in New York Boston on September 2005 by Little, Brown and Company. The novel was chosen because it contains various kinds of adjectives with different functions which can be analyzed as the data source.

\subsection{Method and Technique of Collecting Data}

The method used to collect the data in this study is library research method. The technique used to collect the data is note taking. There are several steps applied in collecting the data. They are reading the novel carefully to find and identifyingthe data examples. The second was finding the adjective derived from noun and verb. The third was copying all the data and saved them in the Microsoft word. The last was classifyinbg the derivational adjectives found in the novel.

\subsection{Method and Technique of Analyzing Data}

The collected data in this study were analyzed using the descriptive qualitative method. This method was applied because the data were in the form of non-numerical data. There were several steps conducted in analyzing the data. First, finding out the types of derivational adjectives found in the novel then analyzed the syntactical functions found in the data.

\subsection{Method and Technique of Presenting Data}

The analysis of this study was presented both in informal and formal methods. In informal method, each problem of the study was presented descriptively in the forms of words and explanation to describe the analysis in detail. Therefore, the analysis could be understood easily. In addition, the second problem was also presented using formal method because it contains tree diagram.

\section{Result and Discussion}

The theory applied in this analysis was the theory of morphology and syntax proposed by Quirk, et al (1985). The data were taken from the novel entitled "Twilight" written by Stephanie Meyer. The data were chosen based on the classification of the adjective. In the form of derivational suffixes forming adjectives there are ten suffixes 
analyzed; they are suffix -ful, -able, -ish, ous, -al, -ic, -less, -y, -ive, -ly. While in syntactic functions there are two functions analyzed; they are predicative and attributive.

\subsection{Derivational Suffixes}

According to Quirk, et al (1985), there are 10 suffixes forming adjectives, they are -ful, -able, -ish, -ous, -al, -ic, -less, -y, -ive, -ly.

\subsubsection{Suffix -ful}

His voice was beautiful.

The adjective beautiful is derived from the base 'beauty' and the word class noun. According to Oxford Advanced Learner's Dictionary, 'beauty' means the quality of being pleasing to the sense or to the mind. When the suffix -ful is attached to the base of the word 'beauty' then the resulting word 'beautiful' becomes adjective which means having beauty or very good. Therefore, the sentence above means that his voice was very good.

\subsubsection{Suffix -able}

I couldn't think of an acceptable response to that.

The base of the word 'acceptable' is acceptwhich is a verb. After the attachment of suffix -able to the base makes the word class change from verb into adjective. According to Oxford Advanced Learner's Dictionary, accept means to take willingly something offered. Meanwhile 'acceptable' means agreed or approved of by most people in a society. Therefore, the sentence describes that the speaker could not think the response which is accepted to that.

\subsubsection{Suffix -ish}

He was more boyish than the others.

The adjective boyish is derived from the base 'boy' and the word class noun. According to Oxford Advanced
Learner's Dictionary, 'boy' means a male child or a young male person. When the suffix -ish is attached to the base of the word 'boy' then the resulting word 'boyish' becomes adjective which means looking or behaving like a boy, in a way that is attractive. Therefore, the sentence above refers to the subject 'he' that has the character more boyish if he is compared with other people.

\subsubsection{Suffix -ous}

His glorious eyes burning into mine.

The base of the word 'glorious' is 'glory' which is noun. After the attachment of suffix -ous to the base the word class changes from noun into adjective. According to Oxford Advanced Learner's Dictionary, glory means fame, praise or honorgiven to somebody because they have achieved something important. Meanwhile 'glorious' means deserving or bringing great fame and success. Therefore, the sentence above explains that his eyes are bringing a great fame.

\subsubsection{Suffix - al}

His expression was skeptical.

The adjective skeptical is derived from the base 'skeptic' and the word class noun. According to Oxford Advanced Learner's Dictionary, 'skeptic' means a person who usually doubts that claims or statements are true, especially those that other people believe in. when the suffix -al is attached to the base of the word 'skeptic' then the resulting word 'skeptical' becomes adjective which means having doubts that a claim or statement is true or that something will happen. Therefore, the sentence above means his expression was dubious. 


\subsubsection{Suffix -ic}

I tried to sound enthusiastic.

The base of the word enthusiastic is 'enthusiast' which is a noun. After the attachment of suffix -ic to the base the word class changes from noun into adjective. According to Oxford Advanced Learner's Dictionary, 'enthusiast' means a person who is very interested in something and spends a lot of time doing it. Meanwhile 'enthusiastic' means feeling or showing a lot of excitement and interest about somebody or something. Therefore, the sentence above means the subject 'I' tried to show a lot of excitement in the way he/she say something to someone.

\subsubsection{Suffix -less}

A slight smile on his flawless lips.

The adjective flawless is derived from the base 'flaw' and the word class is noun. According to Oxford Advanced Learner's Dictionary, 'flaw' means a mistake in something that means it is not correct or does not work correctly. When the suffix -less is attached to the base of the word 'flaw' then the resulting word 'flawless' becomes adjective which means without flaws and therefore perfect. Therefore, the sentence above describes his lips is without flaw and his smile becomes a perfect smile.

\subsubsection{Suffix $-\mathrm{y}$}

I'm not thirsty today.

The base of the word thirsty is 'thirst' which is a noun. After the attachment of suffix $-y$ to the base the word class changes from noun into adjective. 'Thirst' means the feeling of needing or wanting a drink (Oxford Advanced Learner's Dictionary). Meanwhile, thirsty means needing or wanting to drink. Therefore, the sentence above describes the subject 'I' did not want to drink because the sentence above contains negative word 'not'.

\subsubsection{Suffix -ive}

They're all very attractive.

The adjective attractive is derived from the base 'attract' and the word class verb. According to Oxford Advanced Learner's Dictionary, 'attract' means it interests you and makes you want it. When the suffix -ive is attached to the base of the word 'attract' then the resulting word 'attractive' becomes adjective which means having features or qualities that makes something interesting and worth having. Therefore, the sentence above means the speaker praising the people and said they are very interesting.

\subsubsection{Suffix -ly}

Her smile was friendly.

The base of the word friendly is 'friend' which is a noun. After the attachment of suffix -ly to the base the word class changes from noun into adjective. 'Friend' means a person you know well and like, and who is not usually a member of your family (Oxford Advanced Learner's Dictionary). Meanwhile 'friendly' means behaving in a kind and pleasant way because you like somebody or want to help them. Therefore, the sentence above means the girls are having the character of kind and pleasant because people can see from her smile.

\subsection{Syntactic Functions}

There are two syntactic functions analyzed in this study, they are predicative and attributive (Quirk, 1985). Each function also contains tree diagram.

\subsubsection{Predicative}

It sounds reasonable

The word 'reasonable' is a predicative adjective because it appears after the verb 'sounds'. The function of the adjective above is as subject complement and modifies the subject 'it'. 
The adjective here describes the subject 'it' that refers to the previous sentence which sounds sensible.

Morphosyntatically, the adjective 'reasonable' is derived from the noun base 'reason'. It can be seen in the following sentence "I had no reason to be worried." When the suffix -able is attached to the noun 'reason' it becomes reasonable, a derivational adjective. The tree diagram of the sentence above can be illustrated below. This tree diagram only explains the grammatical function of denominal adjective.

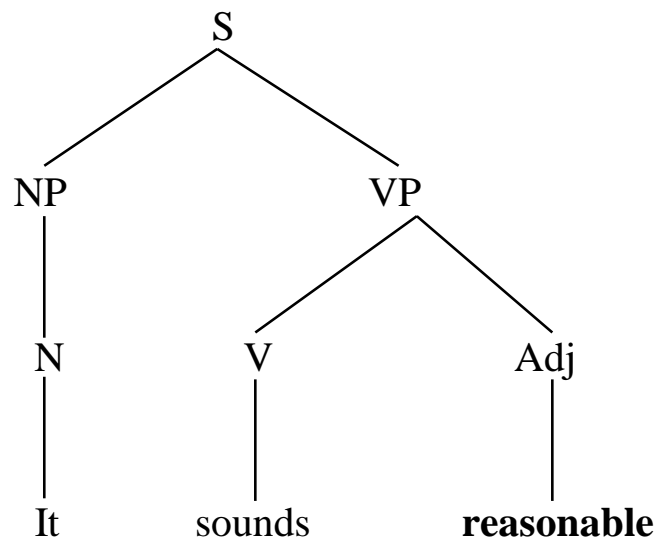

\subsubsection{Attributive}

He asked in a playful tone.

The word 'playful' is an attributive adjective and in this case it premodifies the head of noun 'tone'. It is shown since it appears after the determiner ' $a$ ' and followed by the noun 'tone'. As a noun modifier, 'playful' explains that the tone has the quality of fun; in this case, the tone is good to be listened.

Morphosyntatically, the adjective 'playful' is derived from the verb base 'play'. It can be seen in the following sentence "I had to play volleyball." When the suffix -ful is attached to the verb 'play' it becomes playful, a derivational adjective. The tree diagram of the sentence above can be illustrated below. This tree diagram only explains the grammatical function of deverbal adjective.
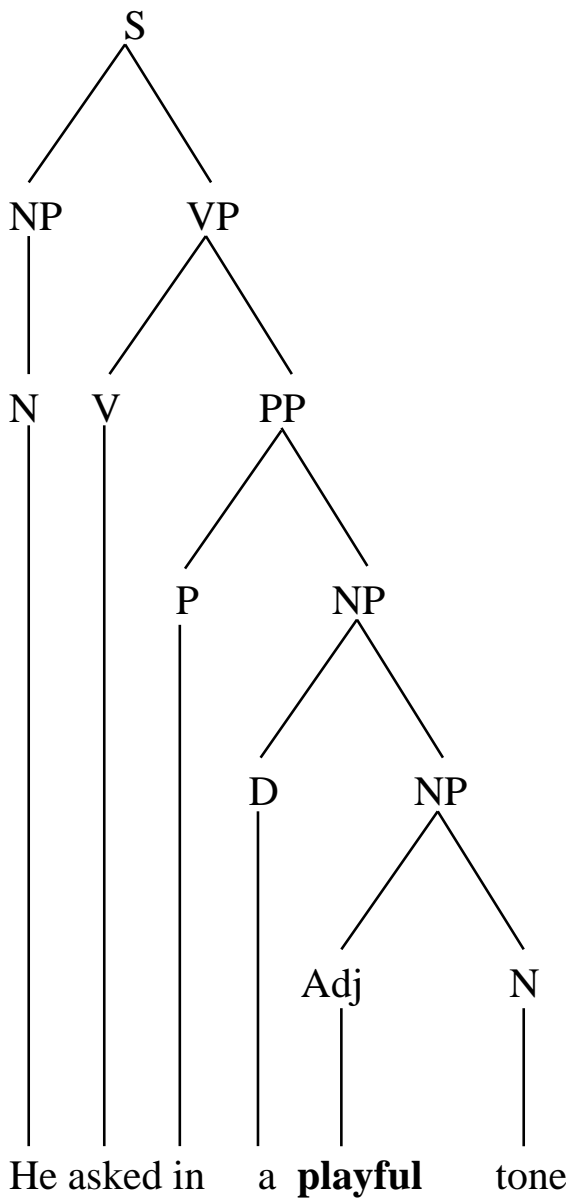

6. Conclusion

Based on the analysis about the derivational suffixes forming adjectives and the syntactic function, it can be concluded that there are ten suffixes that are attached to the base to form new words, they are suffix -ful, -able, -ish, ous, -al, -ic, -less, -y, -ive, -ly. It is attached to the base and changes the word class from noun and verb into adjective. The change of the word class from noun into adjective is called denominal adjective. Meanwhile, the change of the word class from verb into adjective is called deverbal adjective.

The analysis also shows that derivational adjective functions as predicative and attributive adjective. Predicative adjective appears after a verb 
modifies the subject. Meanwhile, attributive adjective appears after determiner and is followed by noun phrase. The function is to premodify the noun or as a noun modifier.

\section{References}

Hornby, A.S. 2010.Oxford Advanced Learner's Dictionary New $8^{\text {th }}$ Edition. Oxford: Oxford University Press.

Katamba, Francis. 1993. Morphology. London: Macmillan Press Ltd

Plag, Ingo. 2002. Word-Formation in English. Cambridge University Press: Cambridge.

Quirk, $\mathrm{R}$ et al. 1985.A Comprehensive of the English Language. Available in

http://www.slideshare.net/ivana 14jovanovic/a-comprehensivegrammar-of-the-englishlanguage-quirk-greenbaumleech-svartvik. Cited on April $8^{\text {th }} 2017$

Quirk, Randolph and Sidney Greenbaum. 1973. A University Grammar of English. London: Longman

Quirk, Randolph and Sidney Greenbaum. 1976. A University Grammar of English. London: Longman 